\title{
Attitudes of University Students Towards Sport
}

\author{
Mehmet Yanik \\ Correspondence: Mehmet Yanik, School of Physical Education and Sport, Balikesir University, Turkey.
}

Received: February 25, 2018

doi:10.11114/jets.v6i5.3047

\author{
Accepted: March 25, 2018 \\ Online Published: April 9, 2018 \\ URL: https://doi.org/10.11114/jets.v6i5.3047
}

\begin{abstract}
The aim of this study is to examine the attitude levels of students receiving education at university level towards sport with regard to certain variables. The research was designed with the scanning model. A "sport attitudes scale" was applied to a total of 547 students, selected by random sampling method, who were studying at Balikesir University.

The research findings revealed that the participants' attitude levels regarding sport were at a "high attitude" level, with an average of $3.70 \pm 058$. It was determined that participants who did sport regularly had a higher attitude level. It was also determined that according to the education department variable, students receiving sports education together with those in the economics faculty had higher attitude levels. As for the grade level variable, it was revealed that the lowest attitude level belonged to third-grade students.

Consequently, with the aim of increasing university students' attitude levels regarding sport, it is recommended that they be given the opportunity to do more sport and that they be given guidance in this direction.
\end{abstract}

Keywords: sport, attitude, university student, attitude towards sport

\section{Introduction}

By conforming with the basic principles of contemporary education, it is possible to raise individuals as healthy people in all senses by educating them physically alongside their intellectual education. This can be realized in line with the aims of general education with the contribution of physical education and sport (Kangalgil, Hunuk and Demirhan, 2006).

When considering sport not only as a way of developing an individual's physical and motor skills but also as a game, as recreation and as a free-time activity, it is also beneficial for social relationships. Sport is effective for adaptability to the environment especially for university students starting a new life. Thanks to sport, it is possible to enter different environments and form new friendships. This will be possible only with a positive attitude towards sport.

In the rapidly developing age of technology, societies, in order to maintain their existence in a healthy environment and to preserve community peace and welfare, benefit from sporting activities. It is known that taking part in activities like these is important for individuals' healthy development, for protecting them from harmful habits in the environmental conditions and for increasing the quality of their lives (Senturk, 2012; Sahin, 2015; Guner, 2015). To achieve this, first of all guidance is needed towards participation in activities like these. This is only possible by developing a positive attitude towards sport in individuals. As is known, attitudes have a powerful effect on an individual's behaviors (Tavsancil; 2014). The factor that determines whether an individual's behavioural responses are positive or negative is that individual's attitudes (Ho, 2008; Morgan, 2010).

Attitude has been the subject of many research studies from several viewpoints, such as how it forms, how it changes, and how it affects the individual and society (Tekkursun, Demir, Ilhan and Arslan, 2017). In some of the studies made, attitude is evaluated as a multifaceted concept, especially in education (Sullivan, 2005; Ozmentes, 2006). The concept of attitude has been defined by many researchers. According to Franzoi (2003), attitude is "a positive or negative evaluation of an object". Cuceloglu (2005), however, defines attitude as "the state of an individual's belief and emotions formed towards people, subjects or events". According to Hogg and Vaughan (2006), attitude is a structure that directs our behaviours, although it is not directly observable.

Attitudes may show a number of changes during the course of our lives. While an individual's immediate surroundings are effective in forming his or her attitudes, especially in the first years of life, these attitudes may undergo a series of changes according to the individual's level of knowledge, socialisation processes and life experiences (Inceoglu, 2010). It is known that attitudes are formed especially during adolescence (12-21 years) and that they take their final form and become permanent during adulthood (21-30 years) (Kagitcibas1, 2005). It is also known that during individuals' 
university period, which generally coincides with their period of adolescence, their attitudes may undergo a number of changes dependent on their experiences (Ozyurek, 2010). Therefore, the importance of organising university experiences in the direction of gaining positive attitudes in students should not be ignored by system executives.

The higher education institutions are the top rung of the ladder on which quality development in the education system is aimed for. In these institutions, educational activities are carried out that are aimed at furthering research and obtaining careers. Moreover, the period of university education is the time when individuals experience the highest degree of physical, intellectual and psychological changes. It is considered that young individuals' displaying of previously-acquired habits for doing sport during this period is a factor in preventing possible negative examples of behaviour.

The role of educational organizations in forming and developing attitudes towards sport is great (Balyan, Balyan and Kiremitci, 2012). With the aim of increasing university students' participation in sport, giving individuals enough opportunities and facilities, and directing and motivating them towards sport will have a positive effect on their attitudes towards sport. Offering sporting services, particularly in branches that were unavailable to students prior to university education, is very important regarding both development of positive attitudes and social development. Lack of these facilities and orientations will have a negative effect on university students' desire to do sport (Bushman, Battista, Swan, Ransdell and Thompson, 2014).

It is known that students' participation in sport has increased in recent years. According to the statistics of university sports federations in Turkey, while the number of students taking part in sporting competitions between universities was 8501 in the year 2000, this figure had reached 26446 by the year 2015, (TUSF, 2015). However, when considering the number of students living in the country, it is seen that in terms of the number of students doing sport outside their lessons, the country is in 45th place among the 55 OECD countries (OECD, 2015). This is also considered to be an indicator of level of attitude towards sport in the country.

Within the context of these data, the aim of this study is to examine the attitudes of students studying at university towards sport with regard to certain variables.

\section{Method}

\subsection{Research Model}

The research is a descriptive study using the scanning model, aiming to determine attitude levels of university students towards sport and to compare them according to various factors.

\subsection{Study Group}

The study group was made up of a total of 547 students continuing their education in various departments of Balikesir University.

Table 1. The demographic data of the participants

\begin{tabular}{|c|c|c|c|}
\hline Variables & & $(\mathbf{N})$ & $\%$ \\
\hline \multirow[t]{2}{*}{ Gender } & Female & 292 & 53.4 \\
\hline & Male & 255 & 46.6 \\
\hline \multirow[t]{2}{*}{ Regularly doing sports } & Yes & 210 & 38.4 \\
\hline & No & 337 & 61.6 \\
\hline \multirow[t]{7}{*}{ Faculty } & Faculty of Education & 111 & 20.3 \\
\hline & Faculty of Arts and Sciences & 153 & 28.0 \\
\hline & Faculty of Economics and Administrative Sciences & 117 & 21.4 \\
\hline & Faculty of Fine Arts & 40 & 7.3 \\
\hline & Faculty of Tourism & 60 & 11.0 \\
\hline & School of Physical Education and Sport & 47 & 8.6 \\
\hline & Other & 19 & 3.5 \\
\hline \multirow[t]{4}{*}{ Grade } & First grade & 120 & 21.9 \\
\hline & Second grade & 147 & 26.9 \\
\hline & Third grade & 142 & 26.0 \\
\hline & Fourth grade & 138 & 25.2 \\
\hline Total & & 547 & 100 \\
\hline
\end{tabular}




\subsection{Data Collection Tools}

The "Sports Attitude Scale for University Students" developed by Kocak (2014) was used as the data collection tool of the study. The scale is of the five-point Likert type and made up of 22 items and three sub-dimensions, namely Psychosocial Development (PsD), Physical Development (PhD) and Mental Development (MD). The internal consistency coefficients for the scale are 0.86 for the first factor, 0.77 for the second factor and 0.76 for the third factor, with a coefficient of 0.89 for the whole scale. According to the reliability analysis of the study, the reliability coefficients are 0.81 for the first factor, 0.72 for the second factor and 0.85 for the third factor, with a coefficient of 0.87 for the whole scale. Considering that coefficients of 0.65 and above are sufficient in studies related to reliability (Cronbach, 1990), it is seen that the reliability levels for the scale and the items it contains are sufficient.

For the analysis of the data in the attitude scale, scores of 1, 2, 3, 4 and 5 were given for the choices "completely disagree", "slightly agree", "moderately agree", "agree" and "completely agree" made for each item. An average score was calculated that included the whole scale. For evaluating the attitude scale, the arithmetic mean, standard deviation and minimum and maximum values for the participants' scores obtained from the scale and its sub-dimensions were calculated. The students' attitudes towards sport according to the developed scale were split into three groups, namely 1- High attitude (3.34-5.00), 2- Moderate attitude (1.67-3.33) and 3- Low attitude (0.00-1.66).

\subsection{Data Analysis}

The data obtained from the study were analyzed using the SPSS programme. At the stage of determining a suitable type of analysis for evaluating the data, the number of subjects $(n=547)$ was examined, as were the data for normal distribution and homogeneity. It was seen that the data met the assumptions for parametric tests.

The data were analyzed using descriptive statistical methods, t-test and single-factor variance analysis (ANOVA). With the aim of determining from which groups significant differences derived, Tukey's test of multiple comparison was performed. A significance level of $(\mathrm{p}<0.05)$ was used for all tests.

\section{Results}

In this section, comments related to the findings obtained from the sports attitude scale applied to the university students within the scope of the research, as well as the results of the statistical analysis of the gathered data regarding the study aims, are given in the form of tables and their explanations have been made.

It was indicated in the research that the point average of the sports attitude scale applied to the university students (n: 547) participating in the study was $3.70 \pm 058$ and that their attitude perceptions were at a high attitude level.

Table 2. T-test results of the Sports Attitude Scale scores for the gender variable

\begin{tabular}{lllll}
\hline Scale Sub-dimensions & $\begin{array}{c}\text { Female (n:292) } \\
\bar{x}_{ \pm S \mathrm{Sd}}\end{array}$ & $\begin{array}{l}\text { Male }(\mathbf{n}: 255) \\
\bar{x} \pm \mathrm{Sd}\end{array}$ & $\mathbf{t}$ & $\mathbf{p}$ \\
\hline Psychosocial Development $(\mathrm{PsD})$ & $3.68 \pm .67$ & $3.66 \pm .63$ & .396 & 0.69 \\
\hline Physical Development $(\mathrm{PhD})$ & $3.95 \pm .65$ & $3.86 \pm .69$ & 1.55 & 0.12 \\
\hline Mental Development $(\mathrm{MD})$ & $3.34 \pm 1.0$ & $3.64 \pm .85$ & -3.64 & 0.00 \\
\hline Total & $3.69 \pm .60$ & $3.71 \pm .55$ & .345 & 0.73 \\
\hline
\end{tabular}

No significant difference was observed between groups in the analysis of participants' sports attitudes made according to gender [ $\mathrm{t}(545)=-0.345, \mathrm{p}>.05]$. It was found that female participants' attitude averages were $(3.69 \pm 0.60)$, while those of male participants were $(3.71 \pm 0.55)$.

In the analysis made according to another variable of the study, that of "doing regular sport", however, it was seen that there was a significant difference between groups. The point average of participants who did sport regularly was found to be $(3.84 \pm 0.51)$, while that of participants who did not do sport regularly was found to be $(3.61 \pm 0.60)$. [ $\mathrm{t}(545)=$ $-0.345, \mathrm{p}<.05]$.

Table 3. ANOVA results of the Sports Attitude Scale scores for the grade variable

\begin{tabular}{llllllll}
\hline Scale Sub-dimensions & $\begin{array}{l}\text { 1.grade } \\
(\mathbf{n : 1 2 0})\end{array}$ & $\begin{array}{l}\text { 2.grade } \\
(\mathbf{n}: 147)\end{array}$ & $\begin{array}{l}\text { 3.grade } \\
(\mathbf{n : 1 4 2})\end{array}$ & $\begin{array}{l}\text { 4.grade (n:138) } \\
\bar{x} \pm \mathrm{Sd}\end{array}$ & $\mathbf{F}$ & $\mathbf{P}$ & Significant Difference \\
& $\bar{x} \pm \mathrm{Sd}$ & $\bar{x} \pm \mathrm{Sd}$ & $\bar{x} \pm \mathrm{Sd}$ & & & & \\
\hline Psychosocial Development $(\mathrm{PsD})$ & $3.77 \pm .66$ & $3.69 \pm .63$ & $3.49 \pm .63$ & $3.76 \pm .66$ & 5.54 & 0.00 & $3<1-2-4$ \\
\hline Physical Development $(\mathrm{PhD})$ & $4.00 \pm .71$ & $3.91 \pm .64$ & $3.74 \pm .69$ & $3.99 \pm .62$ & 4.51 & 0.00 & $3<1-4$ \\
\hline Mental Development $(\mathrm{MD})$ & $3.42 \pm 1.11$ & $3.47 \pm 1.00$ & $3.47 \pm .90$ & $3.55 \pm .81$ & .38 & 0.76 & $\mathrm{p}>0.05$ \\
\hline Total & $3.77 \pm .64$ & $3.71 \pm .58$ & $3.55 \pm .54$ & $3.70 \pm .58$ & 4.61 & 0.00 & $3<1-4$ \\
\hline
\end{tabular}


Table 3 shows the ANOVA results for the grade variable. The results of the analysis made reveal that are statistically significant differences among participants over the whole scale $(\mathrm{p}<0.05)$. It was determined that this variance originated from third-grade students. However, according to the sub-dimensions of the scale, no difference was observed in the mental development sub-dimension ( $\mathrm{p}>0.05)$.

For determining difference in the "faculty/department type" variable, however, one-way variance analysis was performed. The analysis results are given in Table 4.

Table 4. ANOVA results of the Sports Attitude Scale scores for the faculty/department variable

\begin{tabular}{|c|c|c|c|c|c|}
\hline $\begin{array}{l}\text { Scale } \\
\text { Sub-dimensions }\end{array}$ & Faculty & $\mathbf{N}$ & $\bar{x} \pm$ Sd & $\mathbf{F}$ & $\mathbf{p}$ \\
\hline \multirow{8}{*}{$\begin{array}{l}\text { Psychosocial } \\
\text { Development (PsD) }\end{array}$} & 1.Faculty of Education & 111 & $3.66 \pm .691$ & \multirow{8}{*}{6.120} & \multirow{8}{*}{0.00} \\
\hline & 2.Faculty of Arts and Sciences & 153 & $3.58 \pm .627$ & & \\
\hline & 3.Faculty of Economics and Administrative Sciences & 117 & $3.78 \pm .595$ & & \\
\hline & 4.Faculty of Fine Arts & 40 & $3.40 \pm .544$ & & \\
\hline & 5.Faculty of Tourism & 60 & $3.54 \pm .741$ & & \\
\hline & 6.School of Physical Education and Sport & 47 & $4.10 \pm .617$ & & \\
\hline & 7.Other & 19 & $3.67 \pm .560$ & & \\
\hline & Total & 547 & $3.67 \pm .657$ & & \\
\hline \multirow{8}{*}{$\begin{array}{l}\text { Physical Development } \\
\text { (PhD) }\end{array}$} & 1.Faculty of Education & 111 & $4.04 \pm .69$ & \multirow{8}{*}{4.23} & \multirow{8}{*}{0.00} \\
\hline & 2.Faculty of Arts and Sciences & 153 & $3.80 \pm .68$ & & \\
\hline & 3.Faculty of Economics and Administrative Sciences & 117 & $3.94 \pm .68$ & & \\
\hline & 4.Faculty of Fine Arts & 40 & $3.54 \pm .53$ & & \\
\hline & 5.Faculty of Tourism & 60 & $3.94 \pm .66$ & & \\
\hline & 6.School of Physical Education and Sport & 47 & $4.08 \pm .58$ & & \\
\hline & 7.Other & 19 & $4.02 \pm .51$ & & \\
\hline & Total & 547 & $3.91 \pm .67$ & & \\
\hline \multirow{8}{*}{$\begin{array}{l}\text { Mental } \\
\text { (MD) }\end{array}$} & 1.Faculty of Education & 111 & $3.48 \pm .89$ & \multirow{8}{*}{6.30} & \multirow{8}{*}{0.00} \\
\hline & 2.Faculty of Arts and Sciences & 153 & $3.26 \pm 1.0$ & & \\
\hline & 3.Faculty of Economics and Administrative Sciences & 117 & $3.65 \pm .95$ & & \\
\hline & 4.Faculty of Fine Arts & 40 & $3.50 \pm .70$ & & \\
\hline & 5.Faculty of Tourism & 60 & $3.34 \pm 1.07$ & & \\
\hline & 6.School of Physical Education and Sport & 47 & $4.09 \pm .61$ & & \\
\hline & 7.Other & 19 & $3.05 \pm .94$ & & \\
\hline & Total & 547 & $3.48 \pm .95$ & & \\
\hline \multirow{8}{*}{ Total } & 1.Faculty of Education & 111 & $3.73 \pm .59$ & \multirow{8}{*}{7.08} & \multirow{8}{*}{0.00} \\
\hline & 2.Faculty of Arts and Sciences & 153 & $3.58 \pm .57$ & & \\
\hline & 3.Faculty of Economics and Administrative Sciences & 117 & $3.80 \pm .55$ & & \\
\hline & 4.Faculty of Fine Arts & 40 & $3.46 \pm .47$ & & \\
\hline & 5.Faculty of Tourism & 60 & $3.61 \pm .57$ & & \\
\hline & 6.School of Physical Education and Sport & 47 & $4.09 \pm .52$ & & \\
\hline & 7.Other & 19 & $3.65 \pm .52$ & & \\
\hline & Total & 547 & $3.70 \pm .58$ & & \\
\hline
\end{tabular}

Analysis of the faculty/department of study variable reveals that there are significant differences among groups for the whole scale. According to the results of the multiple comparison test (post-hoc Tukey), performed to identify the source of the variance, it was determined that students at the School of Physical Education and Sports and those at the Economics Faculty had higher attitude levels than students in other departments.

\section{Conclusion and Discussion}

In order to raise individuals who, play sports, it is first of all necessary to guide those individuals towards sports, to encourage them to like sports and to provide facilities for them. It is known that the level of positive development of 
attitudes towards sport will reveal the extent to which we have succeeded in this. Scanning the related literature reveals that studies related to this subject on secondary school students have gained in number, whereas relatively fewer studies have been made on university students.

Discussion and comments related to this research, which aims to determine the attitude levels of students studying at Balikesir University towards sport and to compare these levels with regard to various factors, are presented below.

It was indicated in the research that the point average of the sports attitude scale applied to the university students (n:547) participating in the study was 3.70 \pm 058 and that their attitude perceptions were at a high attitude level.

No significant difference was observed between groups in the analysis of participants' sports attitudes made according to gender. In the studies conducted by Goksel et al. (2017), Atalay (2016), and Kocak et al. (2015) on university students, and the study made by Goksel and Caz (2016) on high school students, no statistically significant difference was determined between male and female students for the gender variable. These results also correspond with the results of the present study. Examination of the literature related to university students' attitudes towards sport reveals that there are also studies in which male students have higher attitude scores towards sport than females. The studies conducted on university students by Varol (2017), Kocak (2014), Milanović Z. et al. (2013), Tomik, Olex-Zarychta and Mynarski (2012), Turkmen, Abdurahimoglu, Varol, and Gokdag (2016), Singh and Devi (2013), and Blacklock, Rhodes and Brown (2007) are some of these. The finding of different results in the literature regarding the gender variable may be explained by the fact that the studies were conducted in different organizations and on different groups. Moreover, it is considered that the fact that the organizations where the studies were made provided different levels of facilities for their students may have had an effect on students' attitudes.

The formation and development of attitudes depend on many factors. Participation in sports by university students is an important activity in many senses, especially for their socialization and good health (Akandere, Bastug, Akdogan, 2009). Continuity of participation in the activities carried out may have an effect on attitude. In the study, significant differences in attitude levels of the participants were observed among groups according to how regularly they played sports. It was determined that those who played sports regularly had higher attitude scores. In similar studies in the literature, results that support the research findings have been observed. Yildiz, Ari and Yilmaz (2017), Turkmen et al., (2016), Singh and Devi (2013), and Kangalgil et al., (2006) have also stated in their studies that those who do regular sport have higher attitude levels.

Individuals studying at university, wishing to live new experiences, may find themselves in different social environments. Due to the facilities offered to them by the schools and the areas where they live, students may be involved in areas to do with art, sport or their departments of study where they may develop themselves. A student in music may become involved in various artistic activities, while a student in engineering may find himself in more technical areas in order to develop himself. Yet, thanks to the attitudes formed during their former experiences, or acquired with the facilities offered to them, students may find themselves in a sporting environment. In the present study, significant differences were determined in students' attitude levels towards sport among groups over the whole scale according to the faculty/college of study variable. In the research, it was observed that the highest attitude levels belonged to students in the school of physical education and sports together with those in the economics faculty, while the lowest attitude levels were among students in the fine arts faculty together with those in the faculty of arts and sciences. It is considered that one of the reasons for this result may be that students in the fine arts faculty had been more involved in artistic pursuits than in sports during their former experiences, and that they set aside less time for sport. In the study made by Kizilyalli (2014) on a similar subject on students at Ankara University, it was stated that attitude scores showed differences according to the faculty attended. In another study, however, made by Varol (2017), it was determined that whilst no statistical difference was found according to the faculty variable, the lowest point value was determined in the faculty of religious education.

According to another of the study variables, that of students' grade, significant differences were found among groups for the whole scale. This difference was determined to originate from students in the third year. It may be said that the reasons for this may be that with the beginning of worries about future careers and the burden of career internships, students cannot find enough time to do sport and their areas of interest become directed more towards career development. Moreover, it should not be forgotten that since the study group was in a certain area and university, this result is on a local level.

In similar research made on the subject, there are studies that support the findings of the present study. In the study made by Subramaniam and Silverman (2007) with secondary school students, significant differences were determined according to the class variable. Again, in Altay and Ozdemir's (2006) study, significant differences were found in relation to the level of the class variable. Yet in other studies in the literature, in contrast with the findings of the current study, there are studies in which no differences were found among the groups. In the studies carried out by Dalaman (2017), Varol, Varol and Turkmen (2017), and Goksel and Caz (2016), no differences were determined in sport attitude levels on the class level. 
To sum up, in this study the aim was to examine the attitudes towards sport of Balikesir University students according to certain variables.

In the tests aiming to determine whether there were differences in the scores obtained from the scales showing their personal data by the students taking part in the research, statistically significant differences were encountered among the "gender", "doing regular sport", "faculty/department" and "grade" variables of the students. With these findings it may be said that the attitudes of the participants towards sport were generally at a high level.

By also carrying out this study at other universities, the sports attitude levels of our youth, the future architects of the country, should be determined. It is considered that in the sports policies to be created by our country's administrators, importance should be given to a variety of studies like these with a view to compiling data necessary for projects to be carried out for our youth.

\section{References}

Akandere, M., Bastug, G., \& Akdogan, Z. (2009). The Effects of The Social Environment and Economical State on Their Towards Sports in The Male Marathon Racers, Selcuk University Journal of Institute of Social Sciences, (22). 459-466.

Altay, F., \& Ozdemir, Z. (2006). Comparison of elementary school students' who are studying of the 4th and 5th grade student's primary education in the provincial centers of Ankara province, attitudes toward physical education and sport. 9th International Sport Sciences Congress, 3-5 November 2006; Mugla University. Mugla, Turkey

Atalay, A. (2016). The analysis on sport attitudes of students at high school education in Turkey. Educational Research and Reviews, 11(5), 194. https://doi.org/10.5897/ERR2015.2613

Balyan, M., Balyan, K. Y., \& Kiremitci, O. (2012). Effects of Different Sporting Events on 2nd Level Elementary School Students' Attitude Towards Physical Education and Sport Lessons, Social Skills and Self Efficacy, Selcuk University Journal of Physical Education and Sport Sclence, 14(2), 196-201.

Blacklock, R. E., Rhodes, R. E., \& Brown, S. G. (2007). Relationship between regular walking, physical activity, and health-related quality of life. Journal of Physical Activity and Health, 4(2), 138-152. https://doi.org/10.1123/jpah.4.2.138

Bushman, B. A., Battista, R., Swan, P., Ransdell, L., \& Thompson, W. R. (2014). ACSM's resources for the personal trainer (4th ed.). New York: Lippincott Williams \&Wilkins, 202-211.

Cronbach, L. J. (1990). Essentials of psychological testing. (5th Ed.). New York: Harper Collins Publishers, Inc.

Cüceloglu, D. (2005). İnsan ve Davranışı, [Human and behavior.] 14th ed. Remzi Bookstore, İstanbul.

Dalaman, O. (2017). Investigating female pre-service preschool teachers' attitudes towards sport. Educational Research and Reviews, 12(24), 1242-1252. https://doi.org/10.5897/ERR2017.3417

Franzoi, S. L. (2003). Social Psychology (Third Edition), Boston: Mc. Graw Hill, s. 156.

Goksel, A. G., \& Caz, Ç. (2016). Examining of Physical Education Course Attitudes of Anatolian High School Students, Marmara University Journal of Sport Science, 1(1), 1-10.

Goksel, A. G., Caz, C., Yazici, O. F., \& Ikizler, H. C. (2017). Comparison of Attitudes of Students from Different Departments Towards Sport: The Model of Marmara University. Journal of Sport and Performance Researches, 8(2).123-134

Guner, B. (2015). The Evaluation of the Problems Related to The Women's Not Being Able to Participate in Recreation Activities, Journal of International Sport Sciences, 1(1), 22-29.

Ho, T. K. (2008). A Study of Leisure Attitudes and Benefits for Senior High School Students at Ping-Tung City and County in Taiwan. United States Sports Academy

Hogg, M. A., \& Vaughan, G. M. (2006). Social Psychology. Translated by: Yildiz I. Gelmez A, Utopia Publishing, Ankara

Inceoglu, M. (2010). Attitude Perception Communication. 5th edition. Beykent University Publishing Istanbul, Turkey

Kagitcıbasi, C. (2005). New Man and People,10th Edition, Evrim Publishing Istanbul, Turkey.

Kangalgil, M., Hunuk, D., \& Demirhan, G. (2006). Comparison of Elementary School, High School and University Students' Attitudes Toward Physical Education and Sport, Hacettepe J. of Sport Sciences 2006, 17(2), 48-57.

Kizilyalli, M. (2012). Opinions of Ankara University Students on Female Participation in Sporting Activities. (Unpublished doctoral dissertation). Ankara University, Ankara, Turkey 
Kocak, F. (2014). Undergraduate Students' Attitudes Towards Sport: A Scale Development Study, Spormetre, Ankara University Faculty of Sport Sciences, 12(1), 59-69.

Kocak, F., Tuncel, S., \& Tuncel, F. (2015). Determination of Attitudes of Students Studying at The University Sports Departments Towards in Ankara Sustainability in Sport, Spormetre, Ankara University Faculty of Sport Sciences, 13(1), 29-39.

Milanović, Z., Sporiš, G., Trajković, N., Vračan, D., Andrijašević, M., Pantelić, S., \& Baić, M. (2013). Attitudes towards exercise and the physical exercise habits of University of Zagreb students. Journal Annales Kinesiology, 4(1), 57-70.

Morgan, C. (2010). Introduction to Psychology, Adjusted and Reviewed. Education Academy Publications. Konya, Turkey

OECD, (2015). PISA 2015 Results (Volume III) Students' Well-Being-(C) OECD 2017. Chapter 11, Figure III.11.6 Moderate physical activity in and outside of school, Version 1 -Last updated: 14-Apr-2017, Disclaimer: http://oe.cd/disclaimer. Available on December 28, 2017

Ozmentes, G. (2006). Development of the Attitude Scale towards Music Class, Elementary Education Online, 5(1), 23-29.

Ozyurek, M. (2010). To change of the attitudes toward to disabled people (8th edition). Karatepe Publishing Ankara:

Sahin, A. (2015). Social Progress Inadequacies in The Handicapper: Benefits of Sport in Socializing Process, Journal of International Multidisciplinary Academic Researches, 2-3.

Senturk, H. (2012). Sport-Oriented Attitude Scale: Development, Validity and Reliability. CBU Journal of Physical Education and Sport Sciences, 7(2), 8-18.

Singh, R. K. C., \& Devi, K. S. (2013). Attitude of higher secondary level student towards games and sports. International Journal of Physical Education, Fitness and Sports, 2(4), 80-85. https://doi.org/10.26524/13421

Subramaniam, P. R., \& Silverman, S. (2007). Middle School Students' Attitudes Toward Physical Education, Elsevier, Teaching and Teacher Education, 23, 602-611. https://doi.org/10.1016/j.tate.2007.02.003

Sullivan, T. L. (2005). Care Aides' Attitudes Toward Therapeutic Recreation for The Elderly: Regina Univ.

Tavsancil, E. (2014). Measurement the attitudes and data analysis with SPSS. Nobel publishing, Ankara

Tekkursun, D. G., Cicioglu, H., Ilhan, E., \& Arslan, O. (2017). The attitudes of classroom teacher candidates towards physical education lesson. International Journal of Sport, Exercise \& Training Sciences, 3(4), 120-128. https://doi.org/10.18826/useeabd.319676

Tomik, R., Olex-Zarychta, D., \& Mynarski, W. (2012). Social values of sport participation and their significance for youth attitudes towards physical education and sport, Studies in Physical Culture and Tourism, 19(2), 99-104.

Turkmen, M., Abdurahimoglu, Y., Varol, S., \& Gokdag, M. (2016). The Attitudes of the Students Attending to Faculty of Islamic Sciences towards Sports (The Sample of Bartin University) International Journal of Contemporary Educational Studies (IntJCES), 2(1), 48-59.

TUSF (2015). Sporcu Sayilari Istatistikleri. Available from "http://www.tusf.org/2000-2013-sporcu-sayıları.aspx". Available on February 4, 2018.

Varol, R. (2017). The Study of University Students Attitudes Towards the Sport and University Students Opinions on the Women Participation in Sport Activities (Bartin University Case Study). Unpublished Master's dissertation). Bartin University, Bartin, Turkey

Varol, R., Varol, S., \& Turkmen, M. (2017). Examination of the Attitudes of University Students in Bartin University towards Sports. International Journal of Cultural and Social Studies (IntJCSS), 3(2), 316-329.

Yildiz, A. B., Ari, C., \& Yilmaz, B. (2017). Undergraduate Students' Attitudes Towards Sport (Ankara Yildirim Beyazit University Sample). Mus Alpaslan University International Journal of Sports Science, 1(1), 35-45.

\section{Copyrights}

Copyright for this article is retained by the author(s), with first publication rights granted to the journal.

This is an open-access article distributed under the terms and conditions of the Creative Commons Attribution license which permits unrestricted use, distribution, and reproduction in any medium, provided the original work is properly cited. 